\title{
Disturbances of Bone and Mineral Metabolism in Patients on Hemodialysis
}

\begin{abstract}
Introduction: Unless promptly treated, disturbances of bone and mineral metabolism during the course of chronic kidney disease can lead to serious complications. These abnormalities as well as other factors related to the uremic state affect the skeleton and result in disruption of homeostasis in the bone and mineral turnover. It is manifested by abnormal concentration of phosphorus and calcium in serum and tissues and changes in the concentration of PTH. The spectrum of skeletal abnormalities seen in renal osteodystrophy includes: osteitis fibrosa, osteomalacia, adynamic bone disease (ABD), osteopenia or osteoporosis and combinations of these abnormalities termed mixed renal osteodystrophy.
\end{abstract}

Aim of the study: The aim of our study was to assess biochemical parameters of mineral and bone metabolism in hemodialysis patients.

Patients and Methods: The research involved 30 patients (retrospective type of study), mean age 62.43; fifteen men (50\%) and fifteen women (50\%). Patients were divided into groups in respect to the length of dialysis treatment (group I - up to 5 years, group II - 5-10 years and group III - over 10 years).

Conclusion: Serum phosphorus, calcium, alkaline phosphatase and PTH values were increased with duration of dialysis. The most reliable marker for clinical monitoring of bone disease in dialysis patients is PTH, which correlates well with the values of alkaline phosphatase $(p=0,006)$ and calcium $(p=0,021)$.

Key words: mineral and bone metabolism, PTH, calcium, phosphorus, hemodialysis.

\section{Branislav Gašić1, Dubravka Zrnić-Mićić1, Siniša Miljković ${ }^{2}$}

\author{
${ }^{1}$ Department of Nephrology of the \\ Clinic of Internal Diseases, \\ University Hospital Clinical Center \\ Banjaluka \\ ${ }^{2}$ University of Banjaluka, Faculty of \\ Medicine
}

\section{Contact:}

Dubravka Zrnić-Mićić

Clinic of Internal Diseases

University Hospital Clinical Center Banjaluka

12 beba Street, $780 o o$ Banja Luka

Tel. +38765616536

E-mail:dubravkazm@gmail.com

Submitted: December 18th, 2014 Accepted: February 18th, 2015

\section{Introduction}

Disturbances of bone and mineral metabolism in chronic kidney insufficiency include abnormal concentrations of serum calcium, phosphorus, magnesium, concentration disorders of parathormone (PTH), fibroblast factor of growth 23 (FGF-23) and vitamin D metabolism. ${ }^{1}$ Stimulus for the secretion of PTH and hyperplasia of parathyroid glands is hyperphosphatemia, diminished synthesis of 1,25-dihydroxyvitamin D3 and hypocalcaemia. ${ }^{2,3}$ These disorders as well as uremia affect skeletal system, causing renal osteodystorphy (ROD). The range of changes in the bones include: osteitis fibrosis (manifestation of hyperparathyroidism with increased osteoclastic and osteoblastic activity, peritrabecular fibrosis and accelerated 
bone turnover-high turnover), osteomalacia (decreased mineralization of newly formed osteoid, slow bone turnover-low turnover), adynamic bone disease (ABD) in which we find very low turnover with reduced formation of bone tissue as a consequence of long-term hypocalcaemia resulting from the use of calcium-based phosphorus binders over a long period of time and high concentration of calcium in dialysis fluid, ${ }^{4}$ osteopenia and osteoporosis, and a combination of all of these abnormalities, which is called mixed renal osteodystrophy. In patients on hemodialysis, osteitis fibrosis and ABD have nearly the same frequency of occurrence and in patients on peritoneal dialysis, adynamic bone disease is dominant. 5

Calcium and phosphorus metabolism disturbances occur quite early in chronic kidney insufficiency, and in stage 3 (GFR $30-59 \mathrm{ml} / \mathrm{min} / 1,73 \mathrm{~m} 2$ ) or 4 (GFR $29-15 \mathrm{ml}$ min/1,73m2) we find elevated PTH in the blood ${ }^{2,3}$ and calcified lesions in blood vessels can be seen. Recent studies suggest that chronically elevated FGF-23 directly affects the incidence of occurrence of left ventricular hypertrophy and mortality of KVS complications. ${ }^{6}$ According to the data available, a strong, independent predictor of mortality in kidney insufficiency is hyperphosphatemia; medium strong predictor is elevated level of serum calcium and weak, but a significant predictor is low or high PTH level. The total predicted mortality risk by disorders of mineral metabolism in hemodyalisis patients is $17 \% .^{7}$ Calcium and phosphorus metabolism disturbance is an important factor in the development of cardiovascular calcifications and can often be found in younger hemodialysis patients. ${ }^{8}$

The main aims of treatment of secondary hyperparathyroidism in chronic kidney insufficiency are: prevention of various types of renal osteodystrophy, maintenance of calcium homeostasis, phosphate, vitamin $\mathrm{D}$ and reduction of vascular and soft tissue calcifications. ${ }^{9}$

\section{Aim of the study}

The aim of the research was to evaluate the biochemical parameters of mineral and bone metabolism in patients undergoing chronic hemodialysis program, based on the cross sectional data which were analyzed in March 2013.

\section{Patients and Methods}

We analyzed patients on chronic hemodialysis program (3x4h per week) with urine output less than 400ml/24h. The research included 30 patients, 15 males and 15 females. Patients were divided into groups based on the length of dialysis (HD) duration. The first group comprised of patients who have been on HD for up to 5 years, the second group comprised of patients who have been on HD for 5-10 years, and the third group included patients whose HD has been over 10 years.
Laboratory analyzes were performed in the laboratory of the Clinical Center Banja Luka on the apparatus Cobas E601 and Olympus, as follows: the determination of total serum calcium, serum phosphate, alkaline phosphates and PTH. The range of reference values is 2,20-2,65 mmol/L for calcium, $0,87-1,45 \mathrm{mmol} / \mathrm{L}$ for phosphorus, alkaline phosphates 30-120 U/L, PTH 15-65pg/ml.

Data processing was done in MS Office Word 2007, MS Office Excel 2007 and statistical analysis was done by statistical software package SPSS 21.0. To display quantitative data we used the indicators of descriptive statistics. To compare the differences of frequency of observed characteristics regarding the group of patients we used Pearson's $\chi^{2}$ contingency test. Normality of distribution of the observed characteristics was tested by the Kolmogorov -Smirnov normality test. To compare the mean values of characteristics we used the Student's t-test for independent samples and the Mann -Whitney U-test for two independent samples. In order to determine the degree of correlation we used the Spearman correlation. The values with $\mathrm{p}<0,05$ were taken as statistically significant.

\section{Results}

Considering that disturbance of bone and mineral metabolism leads to a significant deterioration of the quality of life, morbidity, mortality, particularly because of the cardiovascular complications, the recommendation of a good clinical practice guideline (American K/DOQI clinical guidelines), when it comes to the HD patients, is to have the levels of PTH and alkaline phosphates determined every three months and the levels of calcium and phosphorus every month. ${ }^{10}$

Our research included 30 patients, 15 males and 15 females with a mean age of 62,43 years. Duration of dialysis for a period of less than 5 years was in $63,3 \%$, from 5 to10 years in $26,6 \%$ of respondents, and every tenth respondent had dialysis duration of more than 10 years. The average length of dialysis duration in women was 60,8 months $(\mathrm{Cl}$ $95 \%: 3,45-88,15)$, and in men 44,4 months (Cl 95\%: 21, $8-67,0)$. Serum calcium below the reference value was found in $63,1 \%$ of respondents with duration of dialysis less than 5 years, while none of the respondents in this group had calcemia above the normal values. With the increase of duration of dialysis increases the percentage of respondents with hypocalcaemia, while none of the respondents with the duration of dialysis longer than 5 years had any serum calcium below the reference values. There is a statistical significance in relation to the duration of dialysis and calcemia $(\mathrm{p}<0,001)$.

The average value of serum phosphorus increased with the increase of the length of HD duration (I group 1,50 mmol/L (IQ:1,12-2,10), II group 1,60 (IQ: 1,41-1,77mmol/L), III group 2,03 mmol/L (IQ: 1,57-2,84). Reference values of 
phosphorus were in $42,11 \%$ of patients in the first group, $25 \%$ of patients in the second group and there were no reference values in the third group. As for the duration of dialysis of patients, no statistically significant differences in phosphorus were observed (Table1.).

Table 1. Values of phosphorus ( $\mathrm{mmol} / \mathrm{L}$ ) according to the duration of dialysis

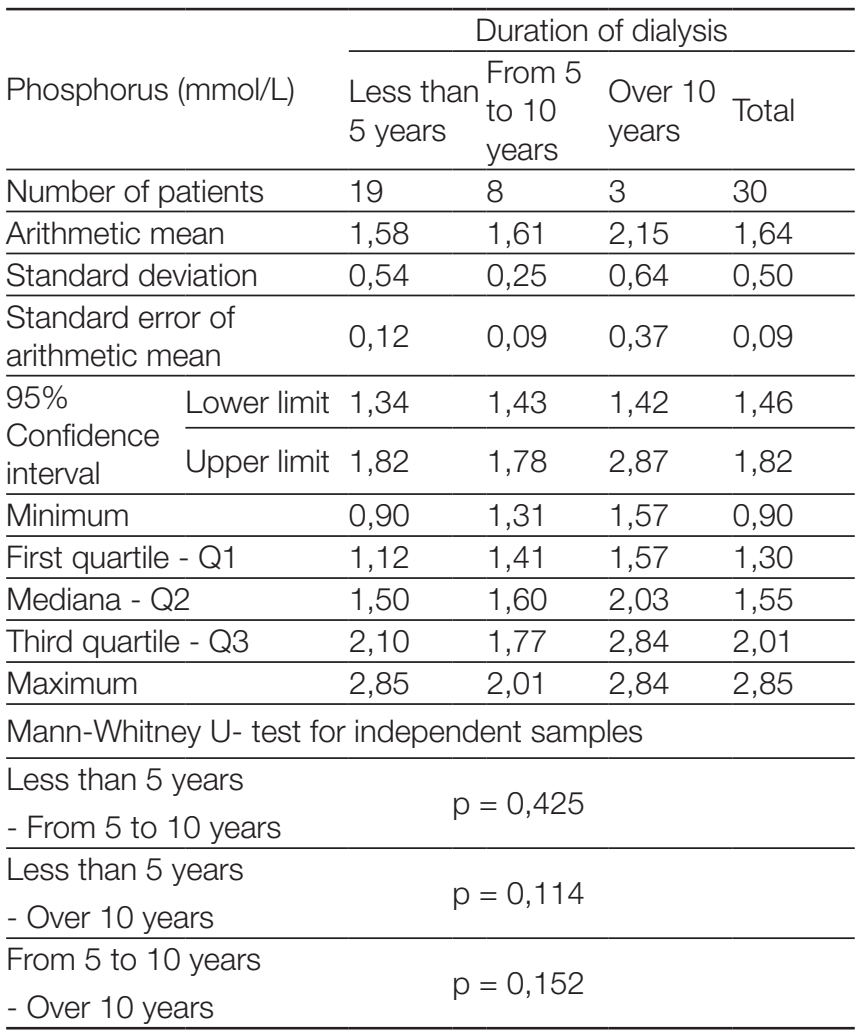

Average value of alkaline phosphates in the first (I) group of patients was 110,9 U/L (Cl 95\% 99,6-122,21), in the second (II) group 115,5 U/L (Cl 95\%:97-134), and in the third (III) group of patients it was 124,33 U/L (Cl 95\%:141,3-149,3). The values of alkaline phosphates in patients with less than 5 years of dialysis duration (I group) were statistically significantly lower than in patients with duration of dialysis longer than 10 years (III group), $\mathrm{p}<0,001$ (Table 2).

Table 2. Values of alkaline phosphates (U/L) according to the duration of dialysis

\begin{tabular}{lcccc}
\hline & \multicolumn{4}{c}{ Duration of dialysis } \\
\cline { 2 - 5 } Alkaline phosphates (U/L) & $\begin{array}{c}\text { Less } \\
\text { than 5 } \\
\text { years }\end{array}$ & $\begin{array}{c}\text { From 5 } \\
\text { to 10 } \\
\text { years }\end{array}$ & $\begin{array}{c}\text { Over 10 } \\
\text { years }\end{array}$ & Total \\
\hline Number of patients & 19 & 8 & 3 & 30 \\
\hline Arithmetic mean & 110,95 & 115,50 & 145,33 & 115,60 \\
\hline Standard deviation & 25,05 & 26,70 & 3,51 & 25,85 \\
\hline $\begin{array}{l}\text { Standard error of arithmetic } \\
\text { mean }\end{array}$ & 5,75 & 9,44 & 2,03 & 4,72 \\
\hline
\end{tabular}

\begin{tabular}{lccccc}
\hline $\begin{array}{l}95 \% \\
\text { Confidence } \\
\text { interval }\end{array}$ & Lower limit & 99,68 & 97,00 & 141,36 & 106,35 \\
\cline { 2 - 6 } & Upper limit & 122,21 & 134,00 & 149,31 & 124,85 \\
\hline Minimum & 60,00 & 63,00 & 142,00 & 60,00 \\
\hline First quartile - Q1 & 95,00 & 101,50 & 142,00 & 97,00 \\
\hline Mediana - Q2 & 121,00 & 123,00 & 145,00 & 123,50 \\
\hline Third quartile - Q3 & 134,00 & 135,00 & 149,00 & 136,00 \\
\hline Maximum & 142,00 & 142,00 & 149,00 & 149,00 \\
\hline Student's t-test for independent samples & & \\
\hline Less than 5 years & $\mathrm{p}=0,676$ & & \\
- From 5 to 10 years & $\mathrm{p}<0,001$ & & \\
\hline Less than 5 years & $\mathrm{p}=0,095$ & & \\
- Over 10 years & & & & \\
\hline From 5 to 10 years & & & & \\
- Over 10 years & & & & \\
\hline
\end{tabular}

Parathormon (PTH) showed an upward trend with the length of dialysis duration; I group $70 \mathrm{pg} / \mathrm{ml}$ (IQ: 61, 0-82, o), II group $81 \mathrm{pg} / \mathrm{ml}$ (IQ 43, o-122, 5), III group $321 \mathrm{pg} /$ ml (IQ: $310,0-380,0)$. The value of PTH was statistically significantly higher in patients from the III group (10 and more years of HD duration) in comparison to the patients from the I group (up to 5 years of HD duration) $\mathrm{p}=0,006$ (Table 3).

Table 3. Correlation of parathormon $(\mathrm{pg} / \mathrm{ml})$ according to the duration of dialysis

\begin{tabular}{|c|c|c|c|c|c|}
\hline \multirow{2}{*}{\multicolumn{2}{|c|}{ Parathormon (pg/ml) }} & \multicolumn{4}{|c|}{ Duration of dialysis } \\
\hline & & \multirow{2}{*}{$\begin{array}{c}\text { Less } \\
\text { than } 5 \\
\text { years } \\
19\end{array}$} & $\begin{array}{l}\text { From } 5 \\
\text { to } 10 \\
\text { years }\end{array}$ & $\begin{array}{l}\text { Over } 10 \\
\text { years }\end{array}$ & Total \\
\hline \multicolumn{2}{|c|}{ Number of patients } & & 8 & 3 & 30 \\
\hline \multicolumn{2}{|c|}{ Arithmetic mean } & 74,68 & 124,88 & 337,00 & 114,30 \\
\hline \multicolumn{2}{|c|}{ Standard deviation } & 32,07 & 120,23 & 37,64 & 102,05 \\
\hline \multicolumn{2}{|c|}{$\begin{array}{l}\text { Standard error of } \\
\text { arithmetic mean }\end{array}$} & 7,36 & 42,51 & 21,73 & 18,63 \\
\hline \multirow{2}{*}{$\begin{array}{l}95 \% \\
\text { Confidence } \\
\text { interval }\end{array}$} & Lower limit & 60,26 & 41,56 & 294,40 & 77,78 \\
\hline & Upper limit & 89,10 & 208,19 & 379,60 & 150,82 \\
\hline \multicolumn{2}{|l|}{ Minimum } & 18,00 & 43,00 & 310,00 & 18,00 \\
\hline \multicolumn{2}{|c|}{ First quartile - Q1 } & 61,00 & 67,50 & 310,00 & 67,00 \\
\hline \multicolumn{2}{|l|}{ Mediana - Q2 } & 70,00 & 81,00 & 321,00 & 77,00 \\
\hline \multicolumn{2}{|c|}{ Third quartile - Q3 } & 82,00 & 122,50 & 380,00 & 112,00 \\
\hline \multicolumn{2}{|c|}{ Maximum } & 154,00 & 414,00 & 380,00 & 414,00 \\
\hline \multicolumn{6}{|c|}{ Mann-Whitney U- test for independent samples } \\
\hline \multicolumn{6}{|c|}{$\begin{array}{l}\text { Less than } 5 \text { years - From } 5 p=0,232 \\
\text { to } 10 \text { years }\end{array}$} \\
\hline \multicolumn{2}{|c|}{$\begin{array}{l}\text { Less than } 5 \text { years - Over } \\
10 \text { years }\end{array}$} & \multicolumn{4}{|c|}{$p=0,006$} \\
\hline \multicolumn{2}{|c|}{$\begin{array}{l}\text { From } 5 \text { to } 10 \text { years - Over } \\
10 \text { years }\end{array}$} & \multicolumn{4}{|c|}{$p=0,066$} \\
\hline
\end{tabular}


It can be noted that patients from the first group (HD duration up to 5 years) have hypocalcemia (63\%), hyperphosphatemia (57\%), elevated PTH $(73,6 \%)$ and alkaline phosphates (52\%), which indicates a bone disease with high turnover. Considering that all patients have been treated with calcium-based phosphorus binders it is necessary to have a continuous education of patients in terms of diet and dietary intake of phosphorus reduction.

With prolonged dialysis duration we found deterioration of biochemical markers of bone metabolism which indicated a deterioration of renal osteodystrophy and development of adynamic bone disease (ABD).

\section{Discussion}

According to the literature, ABD is significant because of the high percentage of representation $(>40 \%$ of patients in HBI stage 5) and high percentage of cardiovascular calcifications and mortality.$^{8-11}$ The incidence of fractures is 2 times higher in patients with low turnover than in high turnover. ${ }^{5}$

According to our research, PTH is in good correlation with calcium ( $p=0,021, \rho=0,42)$, Graph 1., and alkaline phosphataze $(p=0,006, \rho=0,488)$, while the values of phosphorus and alkaline phosphataze are in a statistically significant, medium high positive correlation $(\mathrm{p}=0,017$, $\rho=0,431)$.

\section{Graph 1. Scatter-plot diagram for parathormon (pg/ml) and serum calcium ( $\mathrm{mmol} / \mathrm{l})$}

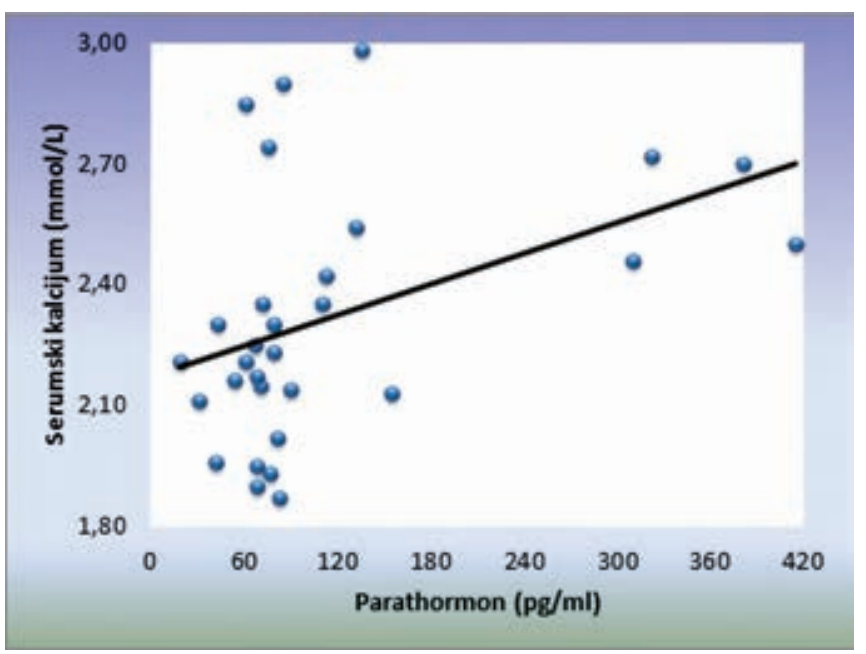

\begin{tabular}{ccc}
\hline$\rho$ & $p$ & $n$ \\
\hline 0,420 & 0,021 & 30 \\
\hline
\end{tabular}

\section{Conclusion}

Based on the results, we can conclude that PTH is the most valid marker for monitoring of bone disease. All these disorders lead to an increase in the prevalence of adverse outcomes in patients undergoing hemodialysis and it is necessary to monitor them in order to improve the quality of life and to reduce morbidity and mortality of patients. Determination of PTH values as well as other biochemical markers is needed for the initial evaluation of patients with bone disease and for the assessment of the therapeutic effect of prescribed therapy.

\section{References}

1. Moe S, Drueke T, Cunningham J, et al. Definition, evaluation, and classification of renal osteodystrophy: A position statement from Kidney Disease: Improving Global Outcomes

(KDIGO). Kidney Int. 2006; 69:1945-1953.

2. Hruska K,Teitelbaurn SL. Renal osteodystrophy.N Engl J Med 1995; 35(3):166-74.

3. Reichel H,Deibert B, Schmidt G, Ritz N. Calcium metabolism in early chronic renal failure: implications for the pathogenesis hyperparathyroidism. Nephrol Dial Transplant 1991;6 (3):62-69.

4. Coresh J, Astor BC, Greene T, Eknoyan G, Levey AS.Prealence of chronic kidney disease and decreased kidney function in the adult US population: Third Natinnal Health and Nutrition Examination Survey. Am J Kidney Dis 2003;41(1):1-12.

5. RJ. Johnson,J. Feehally, J. Floege. Comprehensive clinical nephrology. Fifth edition. Philadelphia: Elsevier Saunders, 2014;969-83.

6. Moe SM, Chertow GM, Coburn JW, et al. Achieving NKF-K/DOQI bone metabolism and disease treatment goals with cinacalcet $\mathrm{HCl}$. Kidney Int. 2005;67:760-771

7. Raggi P, Chertow GM, Torres PU, et al. The ADVANCE study: A randomized study to evaluate the effects of cinacalcet plus lowdose vitamin D on vascular calcification in patients on hemodialysis. Nephrol Dial Transplant. 2011;26:1327-1339.

8. Malluche HH, Mawad H, Monier-Faugere MC. The importance of bone health in end-stage renal disease: Out of the frying pan, into the fire? Nephrol Dial Transplant. 2004;19(suppl 1):9-13.

9. Resić H,Kučukalić Selimović E,Kapidžić A,Kukavica N, Šahović V,Mašinić F. Renalna osteodistrofija kod pacijenata na hemodijalizi. Medicinski žurnal.2009;15(3):106-110.

10. Arenas MD, Alvarez F, GIL MT, Soriano A, EGEA JJ, Millan I, et al. Application of NFK-K/DOQI Clinicl Practice Guidlines for Bone Metbolism and Disease: changes of clincal parctices and their effects on outcomes and quality standards in three haemodialysis units. Nephrol Dial Transplant. 2006; 21(6) 1663-8. 11. London GM, Marty C, Marchais SJ, et al. Arterial calcifications and bone histomorphometry in end-stage renal disease. J Am Soc Nephrol. 2004;15:1943-1951. 


\section{Poremećaji koštano-mineralnog metabolizma kod hemodijaliznih pacijenata}

\section{SAŽETAK}

Uvod: Poremećaji koštano-mineralnog metabolizma u toku hronične bubrežne slabosti mogu dovesti do ozbiljnih komplikacija ukoliko se ne liječe na vrijeme. Ove abnormalnosti, kao i drugi faktori povezani sa uremičnim stanjem, utiču na koštani system, što rezultuje u poremećenom stvaranju-prometu kosti (turnover), a manifestuje se biohemijskim poremećajima serumskog fosfora i kalcija, kalcifikacijom tkiva i promjenama nivoa parathormona (PTH). Spektar koštanih poremećaja u renalnoj osteodistrofiji je: osteitis fibroza, osteomalacija, adinamična bolest kostiju, osteopenija ili osteoporoza i kombinacija svih ovih poremećajamiješana renalna osteodistrofija.

Cilj rada: Ovaj rad je procijena biohemijskih parametara koštano-mineralnog metabolizma kod hemodijaliznih pacijenata.

Ispitanici i metode: Istraživanje je obuhvatilo 30 pacijenata (retrospektivni tip studije), srednje životne dobi 62, 43 god., a od tog broja bilo je 15 žena (50\%) i 15 muškaraca (50\%). Pacijenti su bili podijeljeni u odnosu na hemodijalizni staž na tri grupe (grupa I-do 5 god., grupa II- od 5 do 10 god., grupa III-preko 10 god.).

Zaključak: Vrijednosti serumskog fosfora, kalcija, alkalne fosfataze i PTH su se povećavale sa produženjem vremena provedenog na hemodijalizi. Najpouzdaniji marker za kliničko praćenje koštane bolesti kod dijaliznih bolesnika je PTH, koji dobro korelira sa vrijednostima alkalne fosfataze $(p=0,006)$ i kalcija $(p=0,021)$.

Ključne riječi: mineralno-koštani metabolizam, PTH, kalcij, fosfor, hemodijaliza. 